\title{
59. NAZCA PLATE RADIOLARIAN DISTRIBUTIONS: EVIDENCE FROM DSDP SITES 319, 320, AND 321'
}

\author{
Harvey M. Sachs, Case Western Reserve University, Cleveland, Ohio
}

At Nazca plate Sites 319, 320, and 321, significant numbers of radiolarians were encountered only in the younger parts of the eastern margin sites (320 and 321). In general, the calcareous sediments recovered on Leg 34 were nearly radiolarian free.

In the Bauer Basin (Site 319) the sediment contained virtually no radiolarians at any level. Shipboard smear slides yielded no Radiolaria, but did show a few calcified specimens which might have been replacements. At four levels $(1-5,10 \mathrm{~cm} ; 4-3,80 \mathrm{~cm} ; 6-4,60 \mathrm{~cm}$; and $12-2,75$ $\mathrm{cm}$ ), approximately $10-\mathrm{cc}$ samples were acid treated and washed on a $62 \mu$ sieve. The coarse residues were dried and hand picked. The uppermost sample contained no identifiable specimens; the three lower ones contained a few fragments of robust forms and several unidentified trissocyclids each (Goll, 1968, 1969).

At Site 320, radiolarians, diatoms, and silicoflagellates were abundant and well preserved in the upper parts (320A, Core 1; 320, Core 1), but absent in the rest of the section. The preservation of fragile agglutinated benthonic foraminifera at the top of $320 \mathrm{~A}$, Core 1 implies that this sample was near the sediment water interface (Quilty, this volume), and the radiolarians from this level $(320 \mathrm{~A}-1,0-5 \mathrm{~cm})$ were clearly Pleistocene to modern. Neither that sample nor the core catcher from the same core contained Stylatractus universus (=Axoprunum angelinum). If the North Pacific extinction datum is valid, this indicates that the core catcher is less than about 400,000 years old (Hays, 1970 ), or possibly as young as about 320,000 years if the boundary is diachronous, as suggested by Johnson and Knoll (1975).

In contrast, Sample 320-1, CC contains abundant $A$. angelinum. Since the rare Amphiropalum ypsilon observed had only two chambers on the forked arm before bifurcation, the sample is probably of correlative age with one of Nigrini's (1971) lower Pleistocene Amphiropalum ypsilon or Anthocrytidium angulare zones. Other than $A$. ypsilon, none of the equatorial Pacific stratigraphic index species utilized by Nigrini were recognized. This is one indication of a cooler aspect to the radiolarian fauna at this site, as found also by Molina-Cruz (1975).

In contrast to Site 320 , Site 321 was nearly continuously cored, and Neogene Radiolaria were recovered from the upper part of the section. Core catchers 1-3 (1.5-20.5 m) contain well-preserved Quaternary faunas; core catcher $4(30 \mathrm{~m})$ has a Pliocene or Quaternary assemblage; core catcher $5(39.5 \mathrm{~m})$ contains a sparse assemblage lacking stratigraphically useful forms; core catcher $6(49 \mathrm{~m})$ contains a very sparse earliest late

'CWRU Department of Earth Sciences Contribution 118.
Miocene fauna; and core catchers 7 (58.5 m) -13 (124 m) contain virtually no Radiolaria. In addition to Radiolaria, there are numerous well-preserved diatoms and silicoflagellates in core catchers 1-3.

Core catchers 1-3 contain diverse and well-preserved radiolarian faunas which resemble those of the Panama Basin and Equatorial Pacific. However, at Site 321, Nigrini's equatorial Pacific Quaternary zonation could not be applied, since none of the indicator species except Amphiropalum ypsilon were found. Core catcher 1 contains Pterocanium praetextum, Ommatartus tetrathalamus, and Theoconus minythorax. The Amphirhopalum ypsilon generally show about five chambers on the forked arm before bifurcation. This tends to put this sample in Nigrini's uppermost Quaternary zone, but the nominate form, Buccinosphaera invaginata, was not encountered. The absence of Axoprunum angelinum probably indicates that core catcher 1 sediment is less than about 320,000-400,000 years old (Johnson and Knoll, 1975).

Core catchers 2 and 3 contain assemblages as rich as that of core catcher 1 , but also increasingly abundant Axoprunum angelinum. In both, the Amphirhopalum ypsilon tend to have only two chambers on the forked arm before bifurcation, indicating earlier Quaternary ages. Core catcher 3 is considered to be Quaternary because Pterocanium prismatium was not found, despite the abundance of other Pterocanium species. It is noteworthy that neither Spongaster pentas (lower Pliocene) nor $S$. tetras was encountered at any level in Hole 321.

Core catcher 4, from an ash-rich zone, contains a rather sparse fauna with post-Miocene affinities. Ommatartus tetrathalamus, Axoprunum angelinum and Lamprocyclas maritalis are present. The "Amphirhopalum" present have three completely separate arms. In the absence of any Pterocanium or either Spongaster pentas or $S$. tetras, discrimination between Pliocene and Quaternary is not possible.

Core catcher 5 is nearly barren, with rare robust stylatractoids including one Axoprunum angelinum. Because the range of this form extends into the late Miocene, its presence offers little significant stratigraphic information.

Core catcher 6 contains a sparse fauna with most forms broken. Cannartids dominate, but end caps are almost never preserved. Positive identification of Ommatartus hughesi from several partial samples and a complete end cap strongly indicates that the fauna belongs to the Ommatartus antepenultimus Zone, of earliest late Miocene age (Moore, 1971).

All other core-catcher samples at Site 321 are essentially barren of Radiolaria.

The nearly complete section at Site 321 demonstrates significant changes in radiolarian accumulations. Before 
the earliest late Miocene (321-6, CC), there are no radiolarians preserved in the sediments. At that time, preservation is extremely poor, but becomes progressively better up the section. Cores 1-3 show essentially pristine radiolarians and increasing numbers of diatoms near the top of the section.

Nazca plate radiolarian preservational patterns are striking enough to require comment and interpretation. First, in this region, significant carbonate accumulation is never accompanied by significant opal accumulation (although there is some sediment without either opal of carbonate, viz, the upper part of Site 319, and Site 321, Core 7). Second, radiolarians are not preserved in the Bauer Basin at any age. Finally, on the eastern margin (Sites 320 and 321), radiolarians have been preserved only in the youngest sediments, with preservation quality decreasing from modern to Miocene.

In general, opal preservation is determined by productivity and dissolution. If we assume that geostrophically controlled upwelling is a function of distance from the South American coast, and that there had been covergence of the Nazca plate and South America through much of the Tertiary, then the observed distribution is readily interpreted. At all times, Site 319 has been too far from the coast to show anything except (low productivity) Central Water Mass properties, and thus no opal has accumulated. On the other hand, Site 321 (and, by inference, 320) approached near enough to South America to "feel" its effects on productivity by late Miocene time. Clearly, this speculation is unrealistic. With probable changes in the circulation through the Drake Passage in mid-Tertiary time and the development about the same time of modern bottom water circulation (Savin et al., 1975), neither the assumption of constant circulation patterns nor of constant bottom water conditions is valid for this span of time. In addition, since the effects of these variables all act-in this case-in the same direction, it is difficult to disentangle them.

\section{REFERENCES}

Goll, R.M., 1968. Classification and phylogeny of Cenozoic Trissocyclidae (Radiolaria) in the Pacific and Caribbean Basins. Part 1: J. Paleontol., v. 42, p. 1409-1432. 1969. Classification and phylogeny of Cenozoic Trissocyclidae (Radiolaria) in the Pacific and Caribbean Basins, v. 43 , p. 322-339.

Hays, J.D., 1970. Stratigraphy and evolutionary trends of Radiolaria in North Pacific deep-sea sediments. In Geological investigations of the North Pacific: Hays, J.D. (Ed.), Geol. Soc. Am. Mem. 126, p. 185-218.

Johnson, D.A. and Knoll, A.H., 1975. Absolute ages of Quaternary radiolarian datum levels in the Equatorial Pacific: Quat. Res., v. 5, p. 99-110.

Molina-Cruz, A., 1975. Paleo-Oceanography of the subtropical Southeastern Pacific during Late Quaternary: A study of Radiolaria, opal, and quartz contents of deep-sea sediments: MS Thesis, Oregon State University, Corvallis, Oregon.

Moore, T.C., 1971. Radiolaria. In Tracey, J.I., et al, Initial Reports of the Deep Sea Drilling Project, Volume 8: Washington (U.S. Government Printing Office), p. 727-778.

Nigrini, C.A., 1971. Radiolarian zones in the Quaternary of the Equatorial Pacific Ocean. In Riedel, W.R. and Funnel, B.M. (Eds.), Micropaleontology of oceans: Cambridge (Cambridge University Press), p. 443-461.

Savin, S.M., Douglas, R.G., and Stehli, F.G., 1975. Tertiary marine paleotemperatures: Geol. Soc. America Bull., v. 86, p. $1499-1510$. 